\title{
Avaliação da Composição de Vários Alimentos e Determinação da Cinética Ruminal da Proteína, Utilizando o Método de Produção de Gás e Amônia in Vitro ${ }^{1}$
}

\author{
Fernando Iván Londoño Hernández ${ }^{2}$, Sebastião de Campos Valadares Filho ${ }^{3}$, Mario Fonseca \\ Paulino $^{3}$, Antônio Bento Mancio ${ }^{3}$, Paulo Roberto Cecon ${ }^{4}$, Rogério de Paula Lana ${ }^{3}$, Karla Alves \\ Magalhães ${ }^{5}$, Sandro Luiz Rosa Reis ${ }^{5}$
}

\begin{abstract}
RESUMO - Realizaram-se determinações químicas e estudos sobre a cinética ruminal dos compostos nitrogenados de 24 alimentos concentrados e 10 volumosos, utilizando as medições das concentrações de nitrogênio solúvel em ácido tricloroacético e a produção de gás. Foram utilizados $200 \mathrm{~mL}$ de líquido ruminal e $800 \mathrm{~mL}$ do meio fermentador para a incubação de 100 tubos. Para $400 \mathrm{~mL}$ do meio fermentador foi pesado $1,0 \mathrm{~g}$ de trypticase e adicionado $0,1 \mathrm{~mL}$ de uma solução de microminerais. Para $200 \mathrm{~mL}$ da solução tampão pesaram-se $0,8 \mathrm{~g}$ de bicarbonato de amônia e $7 \mathrm{~g}$ de bicarbonato de sódio e, para preparar $200 \mathrm{~mL}$ da solução de macrominerais, foram pesados $1,15 \mathrm{~g}$ de fosfato de sódio dibásico, 1,25 g de fosfato de potássio dibásico e $0,1 \mathrm{~g}$ de sulfato de magnésio. Foram preparados $100 \mathrm{~mL}$ de solução redutora, pesando 0,64 g de cisteína-HCL, 0,64 g de sulfeto de sódio, adicionando-se $4 \mathrm{~mL}$ de hidróxido de sódio $1 \mathrm{~N}$ e água destilada. A degradação dos compostos nitrogenados dos alimentos foi determinada nos tempos 6 e 12 horas, incubando-se 1,875 mg de $\mathrm{N}$ com 0, 33, 67 e $100 \mathrm{mg}$ de amido, $6 \mathrm{~mL}$ do meio fermentador, $4 \mathrm{~mL}$ da mistura líquido ruminal-meio fermentador e $0,1 \mathrm{~mL}$ da solução redutora utilizando-se $\mathrm{CO}_{2}$. As estimativas das taxas de degradação, nos tempos 6 e 12 horas, mostraram que farelo de glúten de milho, caseína, grão moído de amendoim, raspa de mandioca, silagem de sorgo com e sem inóculo, silagem de milho e capim-gordura apresentaram proteínas de rápida degradação. A mais lenta degradação foi observada para os alimentos: levedura de cana-de-açúcar, farinha de penas, farinha de peixe, cama de frango de cepilha de madeira e capim-braquiária. As estimativas foram maiores que as observadas previamente com o método de inibidores, para os alimentos volumosos. Recomenda-se utilizar o tempo de 12 horas para a avaliação dos concentrados e 6 horas para os volumosos.
\end{abstract}

Palavras-chave: cinética, compostos nitrogenados, produção de gás

\section{Chemical Composition Evaluation and Ruminal Protein Kinetics of Some Feedstuffs Using a Gas and Ammonia Production in vitro Method}

\begin{abstract}
Chemical determinations and kinetics studies of nitrogen compounds of 24 concentrate feedstuffs and 10 grasses were made using the concentrations of soluble nitrogen in TCA and gas production. It was used $200 \mathrm{~mL}$ of ruminal fluid and $800 \mathrm{~mL}$ of medium for 100 vessels. It was used $1.0 \mathrm{~g}$ of trypticase and $0.1 \mathrm{~mL}$ of microminerals solution to prepare $400 \mathrm{~mL}$ of medium. It was used $0.8 \mathrm{~g}$ of ammonium bicarbonate and $7 \mathrm{~g}$ of sodium bicarbonate to prepare $200 \mathrm{~mL}$ of buffer solution and, to prepare $200 \mathrm{~mL}$ of macromineral solution, $1.15 \mathrm{~g}$ of $\mathrm{Na}_{2} \mathrm{HPO}_{4}$ anhydrous, $1.25 \mathrm{~g}$ of $\mathrm{KH}_{2} \mathrm{PO}_{4}$ anhydrous and $0.1 \mathrm{~g}$ of $\mathrm{MgSO}_{4} .7 \mathrm{H}_{2} \mathrm{O}$ were weighed. Reducing solution was prepared with $0.64 \mathrm{~g}$ of cysteine-HCL, $0.64 \mathrm{~g}$ of sodium sulfide and $4 \mathrm{~mL}$ of $1 \mathrm{~N} \mathrm{NaOH}$. The disappearance of nitrogen compounds of feedstuffs was determined at 6 and 12 hours, where $1.875 \mathrm{mg}$ of $\mathrm{N}$ was incubated with $0,33,67,100 \mathrm{mg}$ oh starch, $6 \mathrm{~mL}$ of medium, $4 \mathrm{~mL}$ of ruminal fluid-medium mixture and $0.1 \mathrm{~mL}$ of reducing solution using $\mathrm{CO}_{2}$. Data of degradation rates indicated that corn gluten feed, casein, dry grounded peanut grain, cassava rasp, sorghum silage with or without inoculum, corn silage and honeygrass showed the highest rates of protein degradation and the slowest degradation rates were obtained by sugar cane yeast, feather meal, fish meal, broiler litter using wood rind as adsorvent and signalgrass. Estimates of degradation rates of forage feedstuffs were higher than degradation rates estimated previously by an inhibitor method. It is recommended to use 12 hours for incubation of concentrate feedstuffs and 6 hours for grasses.
\end{abstract}

Key Words: gas production, kinetic, nitrogen compounds

\footnotetext{
${ }_{1}^{1}$ Parte da Tese de Doutorado do primeiro autor, parcialmente financiada pela FAPEMIG.

${ }^{2}$ Aluno de Doutorado do DZO- UFV. E.mail: flondono@alunos.ufv.br

3 Professor do DZO -UFV 36571-000 Viçosa, MG. E.mail: scvfilho@mail.ufv.br

${ }^{4}$ Professor do DPI- UFV 36571-000 Viçosa, MG.

${ }^{5}$ Aluno de graduação UFV.
} 


\section{Introdução}

Uma das grandes vantagens do uso das técnicas in vitro reside na sua rapidez, na uniformidade de condições dentro do microambiente de fermentação e na conveniência de não se manter animais fistulados. Por outro lado, podem ser preditos mais rapidamente os padrões da fermentação e da degradação ruminal in vivo.

A maioria dos microrganismos ruminais não utiliza proteínas, lipídeos e ácidos graxos voláteis como fontes de energia, para seu crescimento, sendo os carboidratos sua principal fonte de energia (Nocek \& Russell, 1988). Os microrganismos que fermentam carboidratos estruturais (celulose, hemicelulose) apresentam lento crescimento e usam somente amônia como fonte de nitrogênio; já os microrganismos que utilizam carboidratos não-estruturais crescem mais rapidamente que os primeiros e podem utilizar amônia, peptídeos e aminoácidos como fonte de nitrogênio (N) para seu crescimento (Russell et al., 1992).

Sabe-se que baixas taxas de crescimento microbiano podem reduzir a taxa de fermentação e o consumo em dietas baixas em energia (Maeng et al., 1975). De acordo com Nocek \& Russell (1988), grandes quantidades de nitrogênio podem ser perdidas como amônia, quando a fermentação dos carboidratos é menor que a da proteína, acarretando redução da síntese de proteína microbiana.

Raab et al. (1983) avaliaram a degradação da proteína, por intermédio da produção de gases e da concentração de amônia, em um período de 24 horas, utilizando vários carboidratos como fonte de energia. Esses autores assumiram que, ao utilizar carboidratos como fonte energética, a produção de gás se torna uma medida da disponibilidade dessa energia para síntese de proteína, independentemente do tipo de carboidrato fermentado. Os autores não encontraram diferenças na produção de gás entre as diferentes fontes de carboidratos, sendo que essa produção foi maior nas primeiras 12 horas, quando a fonte de carboidratos foi o amido. Os resultados foram altamente correlacionados com os obtidos em estudos in vivo. Entretanto, de acordo com essa metodologia, o procedimento requer que a relação entre produção de gás e a concentração de $\mathrm{N}-\mathrm{NH}_{3}$ seja linear.

De acordo com Broderick (1995), a degradação protéica consiste na conversão da proteína dietética até amônia, com as bactérias atuando como os principais microrganismos envolvidos neste evento, seguidas de protozoários ciliados e pequena contri- buição de fungos anaeróbicos. As determinações da degradação da proteína através da liberação de amônia tornam-se difíceis, devido ao fato de a degradação e a síntese da proteína microbiana serem processos que acontecem simultaneamente (Chamberlain \& Thomas, 1979). Por outro lado, existem evidências de peptídeos em elevadas concentrações no líquido ruminal in vivo (Chen et al., 1987) e in vitro (Broderick \& Craig, 1983; Russell et al., 1983; Broderick e Wallace, 1988).

Estudos realizados por Krishnamoorthy et al. (1990), utilizando o método de Raab et al. (1983), para avaliar a contribuição de aminoácidos e peptídeos nas estimativas da degradação da proteína, mostraram que, ao avaliarem o "pool" de amônia exclusivo ou a soma de $\mathrm{N}$-amino, N-peptídico e $\mathrm{N}-\mathrm{NH}_{3}$, não houve diferenças significativas entre os coeficientes de regressão obtidos para os alimentos avaliados.

O objetivo deste trabalho foi estimar os parâmetros cinéticos da degradação da proteína em vários alimentos produzidos no Brasil, por meio da técnica de produção de gás, e a concentração de amônia in vitro.

\section{Material e Métodos}

A dinâmica da degradação dos compostos nitrogenados foi avaliada pela incubação in vitro, utilizando-se o método de produção de gás. O método descrito por Raab et al. (1983) foi modificado, utilizando as medições das concentrações de nitrogênio solúvel em ácido tricloroacético e a produção de gás, em vez de análises de amônia. Foi utilizado, como inóculo, líquido ruminal oriundo de bovino recebendo dieta com $60 \%$ de volumoso (capim-elefante) e $40 \%$ de concentrado (farelo de soja $60 \%$, fubá de milho $20 \%$, farelo de trigo $15 \%$, farinha de sangue $2 \%$, fosfato bicálcico $1 \%$, calcário $1 \%$ e sal mineral $1 \%$ ).

Utilizou-se o método Kjeldahl (AOAC, 1990) para determinar o teor de nitrogênio dos seguintes alimentos: caseína, farelos de soja e de algodão contendo $30 \%$ de casca, glúten de milho, farelo de glúten de milho, farinhas de peixe, de carne e ossos, de sangue, de penas, de vísceras de aves e mista de vísceras de aves e suínos, levedura de cana-de-açúcar, fubá de milho, milho desintegrado com palha e sabugo (MDPS), quirera de milho, grão de milheto moído, grão de sorgo moído, grão de amendoim moído, raspa de mandioca, polpa cítrica, farelo de trigo e as camas de frango contendo como material absorvente casca de café, capim-elefante e cepilha de madeira. 
Avaliaram-se, ainda, as silagens de milho (Zea mays) e sorgo (Sorghum bicolor L. Moench) com ou sem inoculante microbiano, o capim-braquiária (Brachiaria decumbens $\mathrm{cv}$. Basiliski) ( $2^{\circ}$ ano) coletado no início das águas com idade de 45 dias, capimbraquiarão (Brachiaria brizantha Hochst Stapf) coletado no início da seca, capim-andropogon (Andropogon gayanus Kunth) coletado no início das águas com 30 dias de rebrota, capim-gordura (Melinis minutiflora Beauv), capim-braquiária do brejo (Brachiaria radicans Napper), estilosantes guianensis (Stylosanthes guianensis (Aubl.) Sw), cultivar mineirão, coletado no início das águas e o feno de capim-Tifton (Cynodon dactylon) com 5 semanas de idade.

$\mathrm{Na}$ incubação de 100 tubos de $50 \mathrm{~mL}$, foram utilizados $200 \mathrm{~mL}$ de líquido ruminal e $800 \mathrm{~mL}$ do meio fermentador, sendo que o meio fermentador foi preparado de acordo com o seguinte procedimento: para $400 \mathrm{~mL}$ do meio fermentador foi pesado $1,0 \mathrm{~g}$ de trypticase e adicionado $0,1 \mathrm{~mL}$ de uma solução de microminerais $\left(8,0 \mathrm{~g}\right.$ de $\mathrm{FeCL}_{3} \cdot 6 \mathrm{H}_{2} \mathrm{O}, 1,0 \mathrm{~g}$ de $\mathrm{CoCL}_{2} \cdot 6 \mathrm{H}_{2} \mathrm{O}, 10 \mathrm{~g}$ de $\mathrm{MnCL}_{2} \cdot 4 \mathrm{H}_{2} \mathrm{O}$ e $13,2 \mathrm{~g}$ de $\mathrm{CaCL}_{2} \cdot 2 \mathrm{H}_{2} \mathrm{O}$ adicionando $100 \mathrm{~mL}$ de $\mathrm{H}_{2} \mathrm{O}$ destilada) elaborada de acordo com Menke et al. (1979). Para preparar $200 \mathrm{~mL}$ da solução tampão, foram pesados $0,8 \mathrm{~g}$ de bicarbonato de amônia e $7 \mathrm{~g}$ de bicarbonato de sódio e, para preparar $200 \mathrm{~mL}$ da solução macrominerais, $1,15 \mathrm{~g}$ de fosfato de sódio dibásico, $1,25 \mathrm{~g}$ de fosfato de potássio dibásico $\left(\mathrm{KH}_{2} \mathrm{PO}_{4}\right)$ e $0,1 \mathrm{~g}$ de sulfato de magnésio $\left(\mathrm{MgSO}_{4} 7 \mathrm{H}_{2} \mathrm{O}\right)$. Também foram preparados $100 \mathrm{~mL}$ de uma solução redutora, sendo pesados: $0,64 \mathrm{~g}$ de cisteína-HCL, 0,64 $\mathrm{g}$ de sulfeto de sódio $\left(\mathrm{Na}_{2} \mathrm{~S}_{2} \mathrm{H}_{2} \mathrm{O}\right)$, adicionando $4 \mathrm{~mL}$ de hidróxido de sódio $\mathrm{NaOH} 1 \mathrm{~N}$ e água destilada.

Após a retirada do líquido ruminal, este foi filtrado, inicialmente, em camada dupla de gase e, na sala de incubação, em camada quádrupla. Aos $200 \mathrm{~mL}$ do líquido ruminal foram adicionados $200 \mathrm{~mL}$ do meio fermentador, infundindo-se $\mathrm{CO}_{2}$. Cada alimento foi incubado nos tempos 6 e 12 horas, na quantidade de $1,875 \mathrm{mg}$ de $\mathrm{N}$, adicionando-se 0,33, 67 e $100 \mathrm{mg}$ de amido a cada tubo de incubação, além de $6 \mathrm{~mL}$ do meio fermentador, $4 \mathrm{~mL}$ da mistura do líquido ruminal e do meio fermentador e $0,1 \mathrm{~mL}$ da solução redutora, sempre infundindo-se $\mathrm{CO}_{2}$ para manter as condições anaeróbicas. Foram feitas medições do $\mathrm{pH}$ na mistura do líquido ruminal e meio fermentador e em uma amostra dos tubos de incubação (frascos de $50 \mathrm{~mL}$ ). Foram colocadas borrachas vedantes nos tubos e lacrados com tampas metálicas. As incubações foram realizadas na sala de incubação, $\mathrm{a} 39^{\circ} \mathrm{C}$, colocando os tubos em cima de uma mesa orbital com agitação de 38,6 rpm.

Após o vedamento dos tubos, foi estimada a produção de gás, por meio da medição da pressão, utilizando um voltímetro digital (FLUKE 8060A True RMS Multimeter acoplado a um conversor de $12 \mathrm{v}$ ), sendo posteriormente adicionado $1,0 \mathrm{~mL}$ de ácido tricloroacético (TCA) 55\% e os frascos guardados em geladeira. Para descontar o volume de gás oriundo do líquido do rúmen e do meio fermentador, dois frascos para cada tempo de incubação foram incubados sem amostra (branco); dessa forma, para cada tempo de leitura, o volume de gás dos frascos com amostra foi subtraído do volume dos frascos sem amostra. Os tubos de 6 e 12 horas foram mantidos sob agitação na sala de incubação e, após o período de incubação, foi medida a produção de gás, colocado TCA na mesma proporção que para os tubos brancos e guardados em geladeira. Posteriormente, todos os tubos $(0,6$ e 12 horas) foram centrifugados a $15.300 \mathrm{~g} \mathrm{e} 4^{\circ} \mathrm{C}$, durante 15 minutos, e o sobrenadante foi conservado a $4^{\circ} \mathrm{C}$ até a realização das análises correspondentes.

Foram feitas determinações de matéria seca (MS), matéria orgânica (MO), matéria mineral (MM) e extrato etéreo (EE), seguindo os procedimentos do (AOAC, 1990), os carboidratos totais (CHT) foram calculados como CHT (MS) $=100-\% \mathrm{~PB}+\% \mathrm{EE}+$ $\% \mathrm{MM})$, e carboidratos não-fibrosos (CNF), obtidos pela fórmula $\mathrm{CNF}=\mathrm{MO}-\left(\% \mathrm{~PB}+\% \mathrm{EE}+\% \mathrm{FDN}_{\mathrm{cp}}\right)$, em que $\mathrm{FDN}_{\mathrm{cp}}$ corresponde à fibra em detergente neutro isenta de cinzas e de proteínas (Sniffen et al., 1992). Foram determinadas, ainda, fibra em detergente neutro indigestível $\left(\mathrm{FDN}_{\mathrm{I}}\right)$, fibra em detergente ácido indigestível (FDA ${ }_{\mathrm{I}}$ ) e lignina (Van Soest et al., 1991). O teor de fibra em detergente neutro indigestível $\left(\mathrm{FDN}_{\mathrm{I}}\right)$ foi obtido por intermédio do resíduo indigestível, após 144 horas de incubação em líquido ruminal; o nitrogênio não-protéico (NNP), de acordo com Licitra et al. (1996); e as proteínas insolúveis em detergente neutro (PIDN) e em detergente ácido (PIDA), pela multiplicação dos valores de nitrogênio insolúvel em detergente neutro (NIDN) e nitrogênio insolúvel em detergente ácido (NIDA) por 6,25. A composição bromatológica dos alimentos concentrados e volumosos encontra-se, respectivamente, nas Tabelas 1 e 2 .

As amostras foram moídas em moinho de bola e incubadas em duplicata em três dias diferentes, utilizando a caseína como alimento padrão. Os cálculos da degradação da proteína dos alimentos avaliados 


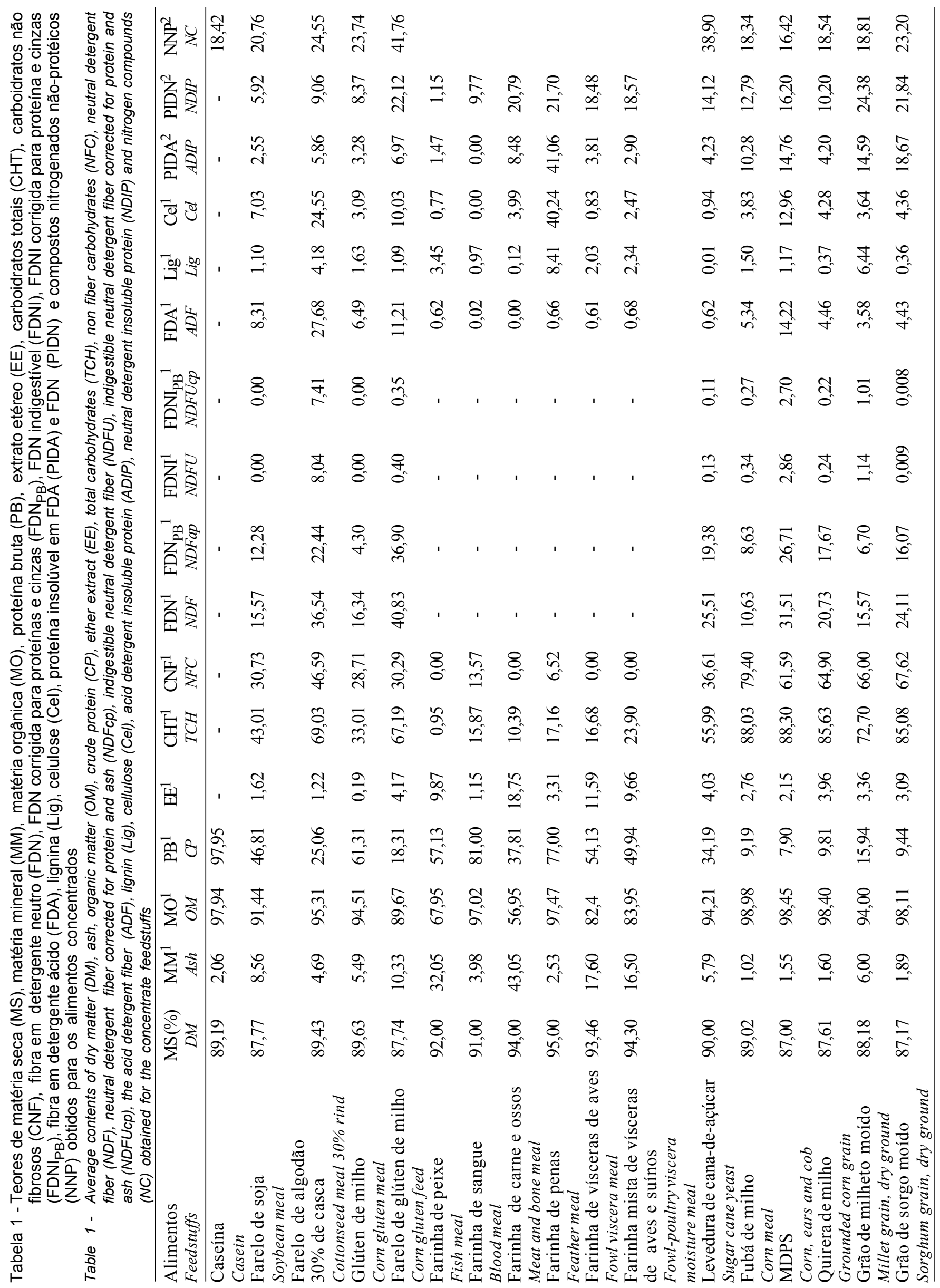




\begin{tabular}{|c|c|c|c|c|c|c|c|}
\hline 艺 & 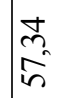 & $\hat{\sigma}$ & $\hat{n}$ & $\stackrel{\approx}{=}$ & $\begin{array}{l}\hat{n} \\
\hat{n}\end{array}$ & $\begin{array}{l}\infty \\
\infty \\
\infty \\
\infty \\
\infty\end{array}$ & 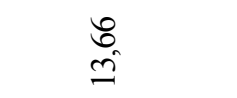 \\
\hline 光 & Î & $\underset{\vec{i}}{\vec{i}}$ & $\stackrel{0}{\stackrel{1}{*}}$ & $\frac{R}{6}$ & $\begin{array}{l}0 \\
\stackrel{2}{\infty} \\
\infty\end{array}$ & $\begin{array}{l}\stackrel{\infty}{\sim} \\
\dot{m}\end{array}$ & $\begin{array}{l}8 \\
\text { so }\end{array}$ \\
\hline 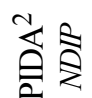 & $\stackrel{0}{=}$ & $\begin{array}{l}\text { O } \\
\stackrel{-}{=}\end{array}$ & $\stackrel{P}{=}$ & $\vec{\pi}$ & $\begin{array}{l}\stackrel{\infty}{\sim} \\
\underset{ \pm}{ \pm}\end{array}$ & $\stackrel{2}{\vec{n}}$ & $\stackrel{R}{\stackrel{0}{0}}$ \\
\hline $\bar{\Xi}$ & $\stackrel{\infty}{=}$ & $\hat{m}$ & $\stackrel{n}{\hat{n}}$ & $\begin{array}{l}\infty \\
n \\
0 \\
0\end{array}$ & $\hat{\sigma}$ & $\vec{n}$ & ลેे \\
\hline త & $\underset{f}{\stackrel{g}{f}}$ & $\stackrel{\mathbb{N}}{\approx}$ & $\stackrel{?}{f}$ & $\stackrel{n}{n}$ & $\stackrel{\infty}{-}$ & $\underset{m}{\mathbb{N}}$ & (ి) \\
\hline 茛: & $\mid \begin{array}{l} \pm \\
\dot{I} \\
-\end{array}$ & $\underset{\infty}{\forall}$ & $\begin{array}{l}\text { ర్ } \\
\qquad\end{array}$ & 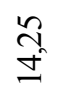 & $\frac{\dot{t}}{\stackrel{+}{d}}$ & $\begin{array}{l}8 \\
\text { iे }\end{array}$ & $\begin{array}{l}\infty \\
\text { î } \\
\text { ले }\end{array}$ \\
\hline 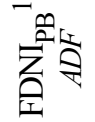 & ס & ì & مn & $\stackrel{\hat{n}}{m}$ & $\stackrel{m}{n}$ & $\stackrel{\mathscr{F}}{\mathfrak{r}}$ & $\stackrel{\vec{\sigma}}{=}$ \\
\hline 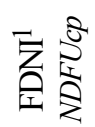 & के & $\stackrel{n}{i}$ & $\stackrel{8}{8}$ & సે & $\begin{array}{l}\infty \\
\infty \\
n\end{array}$ & $\underset{n}{\stackrel{t}{n}}$ & $\stackrel{+}{=}$ \\
\hline 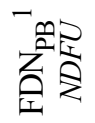 & 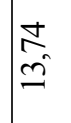 & 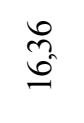 & $\begin{array}{l}n \\
\tilde{n} \\
\dot{n}\end{array}$ & $\begin{array}{l}\dot{n} \\
\hat{n}\end{array}$ & $\underset{f}{\stackrel{n}{\sigma}}$ & $\frac{\stackrel{P}{F}}{\mathscr{f}}$ & $\overrightarrow{0}$ \\
\hline 竞害 & $\overrightarrow{\widehat{N}}$ & $\begin{array}{l}\tilde{n} \\
\infty \\
\infty\end{array}$ & $\begin{array}{l}\infty \\
\stackrel{\circ}{q}\end{array}$ & $\begin{array}{l}\text { ¿े } \\
\text { ले }\end{array}$ & \begin{tabular}{l}
$\mathscr{\infty}$ \\
\multirow{f}{*}{}
\end{tabular} & $\frac{\infty}{\tilde{n}}$ & $\begin{array}{l}\text { f } \\
\text { in } \\
i n\end{array}$ \\
\hline 考喪 & $\begin{array}{l}7 \\
0 \\
\infty \\
n\end{array}$ & \&. & $\begin{array}{l}\tilde{n} \\
\hat{q}\end{array}$ & $\overrightarrow{\tilde{N}}$ & $\begin{array}{l}\text { ț } \\
\text { i }\end{array}$ & $\underset{\text { f }}{\text { f }}$ & તิ \\
\hline 志至 & 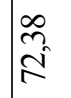 & $\hat{n}$ & $\begin{array}{l}8 \\
\dot{+} \\
+\end{array}$ & $\stackrel{n}{\stackrel{2}{i}}$ & gे & $\frac{5}{2}$ & $\overrightarrow{\widetilde{N}}$ \\
\hline 島 & તิ & 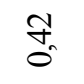 & is & $\begin{array}{l}n \\
\hat{n}\end{array}$ & $\stackrel{\infty}{\infty}$ & సે & $\mathscr{\infty}_{0}$ \\
\hline $\bar{m} \delta$ & $\begin{array}{l}\text { ¿ू } \\
\text { ñ }\end{array}$ & $\begin{array}{l}n \\
n \\
n\end{array}$ & $\stackrel{\infty}{\sigma}_{6}^{+}$ & 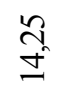 & $\frac{m}{n}$ & $\begin{array}{l}\text { Rn } \\
\text { İ }\end{array}$ & $\begin{array}{l}\vec{n} \\
\hat{n}\end{array}$ \\
\hline$\stackrel{0}{\Sigma}$ & $\begin{array}{l}n \\
2 \\
8\end{array}$ & $\begin{array}{l}n \\
\text { ñ } \\
2\end{array}$ & $\begin{array}{l}\text { ô } \\
\text { id }\end{array}$ & $\begin{array}{l}n \\
\tilde{n} \\
\dot{\sigma}\end{array}$ & $\frac{\hat{\sigma}}{\infty}$ & $\begin{array}{l}\text { ஜ } \\
\dot{\infty}\end{array}$ & $\stackrel{n}{\alpha}$ \\
\hline$\sum \underset{\Sigma}{\Sigma}$ & ån. & $\underset{n}{6}$ & $\stackrel{\infty}{\pi}$ & $\underset{\tilde{f}}{\tilde{f}}$ & ๙ิ & $\begin{array}{l}t \\
\ddot{n}\end{array}$ & ? \\
\hline$\sum_{\substack{\infty \\
\Sigma}}^{\square}$ & $\frac{8}{2}$ & $\underset{\infty}{\stackrel{\Delta}{\infty}}$ & $\hat{\infty}$ & $\frac{O}{\infty}$ & $\begin{array}{l}n \\
\cdots \\
\infty \\
\infty\end{array}$ & $\begin{array}{l}\text { ते } \\
\text { ڤे }\end{array}$ & $\begin{array}{l}6 \\
8 \\
+\end{array}$ \\
\hline 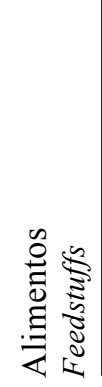 & 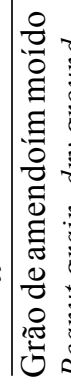 & 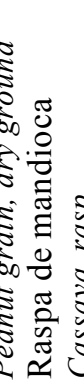 & {$\left[\begin{array}{l}\Xi \\
0 \\
0 \\
\frac{\pi}{2} \\
0 \\
0 \\
0\end{array}\right.$} & $\frac{0}{0}$ & 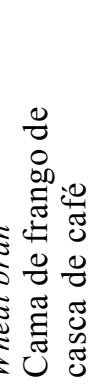 & 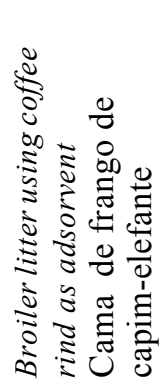 & 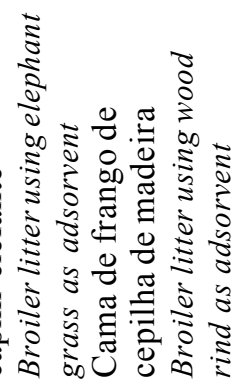 \\
\hline
\end{tabular}




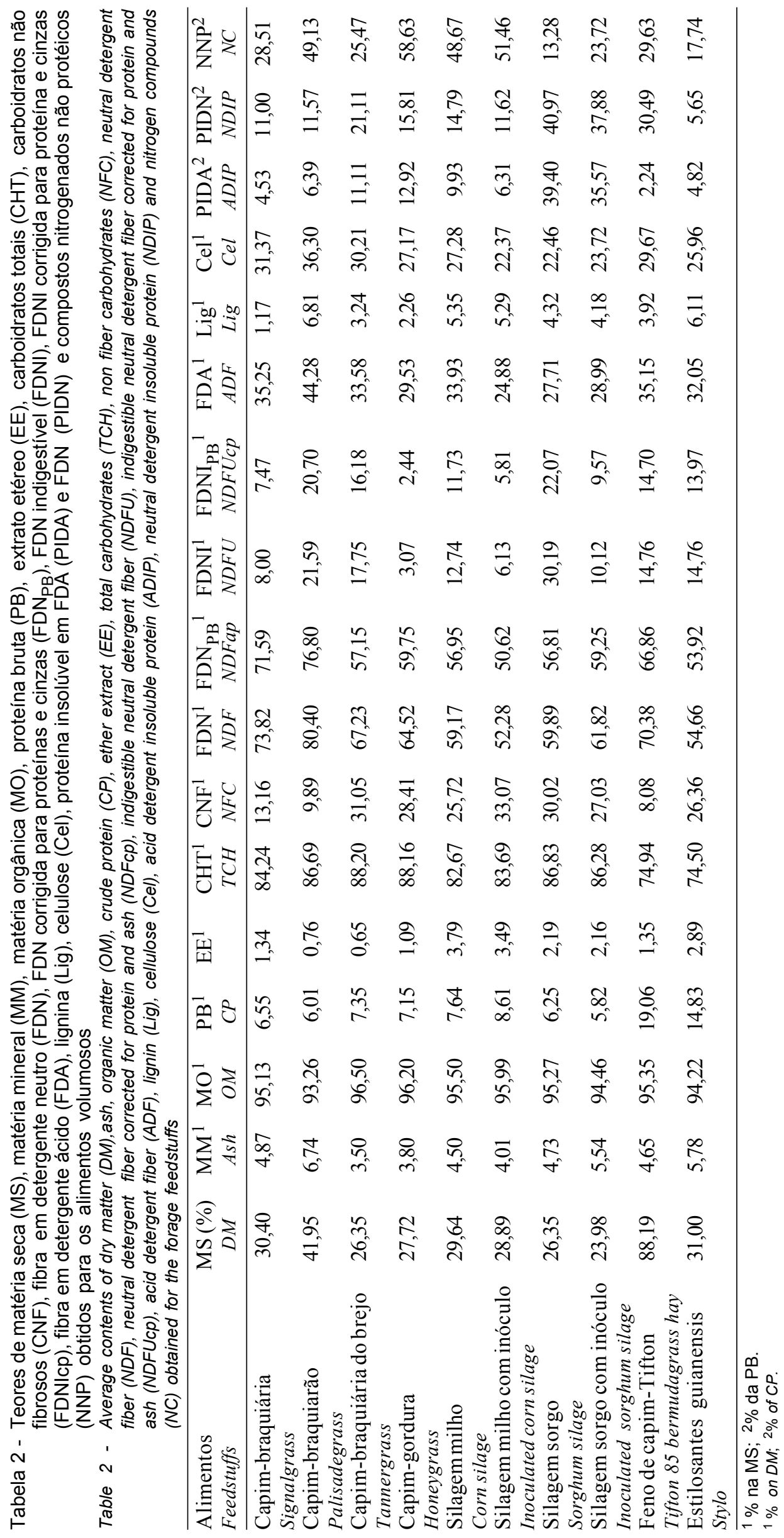


foram realizados de acordo com as seguintes explicações: 1) foram ajustadas equações de regressão linear simples entre as concentrações de nitrogênio $\mathrm{N}$-solúvel em TCA (Y, mg/tubo) nos tubos contendo $0,33,67$ e $100 \mathrm{mg}$ de amido dos diferentes alimentos incubados nos tempos 6 e 12 horas e sua produção de gás $(\mathrm{X}, \mathrm{mL} /$ tubo $) ; 2)$ a conversão da voltagem em produção de gás foi realizada utilizando o fator " $\mathrm{C}$ " de 8,67 (Pell \& Schofield, 1993) 3) o intercepto $b_{0}$ representou a quantidade de $\mathrm{N}$ recuperado no momento em que não houve disponibilidade de carboidratos fermentáveis e, conseqüentemente, não houve síntese de proteína microbiana; e 4) a diferença entre o intercepto $\mathrm{b}_{0}$ e a quantidade de $\mathrm{N}$ no branco representou a quantidade de $\mathrm{N}$ recuperado dos alimentos incubados:

Nrecuperado $=\mathrm{b}_{0}-\mathrm{N}$ branco

Assim, as taxas de degradação foram calculadas por intermédio de:

$\mathrm{Kd}=\mathrm{Ln}\left[1-\left(\mathrm{b}_{0}-\mathrm{N}\right.\right.$ branco $) / \mathrm{N}$ incubado $] /$ tempo

A proteína de escape foi calculada como: Pe $(\%)=[K p /(K d+K p)]$, assumindo-se uma taxa de passagem de $0,05 / \mathrm{h}$.

Os dados sobre as taxas de degradação para os tempos 6 e 12 horas dos diferentes alimentos foram comparados por meio do teste " $t$ " para dados emparelhados, a $5 \%$ de probabilidade.

\section{Resultados e Discussão}

As estimativas das concentrações de $\mathrm{N}$-solúvel em TCA (y), em função da produção de gás (x), obtidas após 12 horas de incubação para alimentos concentrados, são mostradas na Tabela 3. Os interceptos foram bastante variados entre os alimentos avaliados, indicando diferenças nas degradabilidades.

Foram observados interceptos próximos entre grupos de alimentos: farelo de soja $(4,70)$ e farinha vísceras de aves $(4,74)$; caseína $(5,44)$ e cama de frango contendo casca de café como material absorvente $(5,49)$; fubá de milho $(4,92)$ e quirera de milho $(4,91)$; e farelo de glúten de milho $(5,63)$, raspa de mandioca $(5,66)$ e grão de amendoim moído $(5,60)$, indicando que esses alimentos apresentaram degradabilidades semelhantes.

Foi encontrada também relação linear entre a produção de gás e a concentração de nitrogênio solúvel em TCA para os volumosos avaliados, após 6 horas de incubação (Tabela 4). Os interceptos foram diferentes para os volumosos avaliados, sendo esse valor maior para a silagem de sorgo $(4,59)$ e menor para o capim-braquiária e o feno de capim-tifton, 3,77 e 3,79, respectivamente.

Já os coeficientes da regressão foram semelhantes entre capim-braquiária do brejo, silagem de milho inoculado e feno de capim-tifton e próximos à 0,1 . Também foram encontrados coeficientes semelhantes entre capim-braquiária, capim-gordura, silagem de milho e silagem de sorgo inoculado: 0,$24 ; 0,25 ; 0,29$; e 0,20 , respectivamente, e o maior coeficiente foi encontrado para o estilosantes guianensis.

Russell et al. (1983) demonstraram que a concentração de amônia foi inversamente proporcional à taxa de fermentação de carboidratos. Por outro lado, de acordo com Miller (1982), a concentração de amônia é influenciada também pela quantidade de carboidratos fermentados.

Na Figura 1 é mostrada a relação entre a concentração de nitrogênio solúvel em TCA (y) e a concentração de amido para a caseína após 12 horas de incubação.

Os resultados apresentaram linearidade entre a concentração de nitrogênio solúvel em TCA e a quantidade de amido, assim como entre a concentração de $\mathrm{N}-\mathrm{NH}_{3}$ e a produção de gás. O coeficiente de regressão da caseína foi de 0,026 , ou seja, $0,026 \mathrm{mg}$ de nitrogênio foi consumido/mg de amido adicionado, sendo esse valor próximo ao obtido na pesquisa de Raab et al. (1983), de 0,023, avaliando a degradabilidade in vitro da caseína utilizando até $200 \mathrm{mg}$ de amido e 24 horas de incubação.

As taxas de degradação da proteína $(\mathrm{Kd})$ e a proteína de escape dos alimentos concentrados obtidas com 6 e 12 horas de incubação estão apresentadas na Tabela 5. Ao comparar as taxas de degradação pelo teste " $t$ " nos dois tempos de incubação (6 e 12 horas) para os alimentos concentrados, foram encontradas diferenças significativas $(\mathrm{P}<0,05)$.

As estimativas das taxas de degradação, nos tempos 6 e 12 horas, mostraram que os alimentos farelo de glúten de milho, caseína, grão de amendoim moído e raspa de mandioca apresentaram proteínas de rápida degradação e a mais lenta degradação foi observada para levedura de cana-de-açúcar, farinha de penas, farinha de peixe e cama de frango contendo como material absorvente cepilha de madeira.

As estimativas médias das taxas de degradação do farelo de algodão com $30 \%$ de casca, após 12 horas de incubação, foram semelhantes às obtidas por Neutze et al. (1993) de 0,086/h, utilizando a 
Tabela 3 - Estimativas das concentrações de N-solúvel em TCA (y) em função da produção de gás (x), obtidas após 12 horas de incubação para os alimentos concentrados, e coeficientes de determinação $\left(r^{2}\right)$

Table 3 - Estimates of N-soluble in TCA concentrations in function of gas production, obtained after 12 hours of incubation for the concentrate feedstuffs, and coefficients of determination $\left(r^{2}\right)$

\begin{tabular}{|c|c|c|}
\hline $\begin{array}{l}\text { Alimentos } \\
\text { Feedstuffs }\end{array}$ & $\begin{array}{l}\text { Equações de regressão } \\
\text { Regression equations }\end{array}$ & $\mathrm{r}^{2}$ \\
\hline Caseína & $\hat{\mathrm{Y}}=5,445-0,130 \mathrm{x}$ & 0,93 \\
\hline Casein & & \\
\hline $\begin{array}{l}\text { Farelo de soja } \\
\text { Soybean meal }\end{array}$ & $\hat{Y}=4,704-0,106 x$ & 0,92 \\
\hline $\begin{array}{l}\text { Farelo de algodão } 30 \% \text { casca } \\
\text { Cottonseed meal } 30 \% \text { rind }\end{array}$ & $\hat{Y}=4,619-0,114 x$ & 0,99 \\
\hline $\begin{array}{l}\text { Glúten de milho } \\
\text { Corn gluten meal }\end{array}$ & $\hat{Y}=3,480-0,078 x$ & 0,93 \\
\hline $\begin{array}{l}\text { Farelo de glúten de milho } \\
\text { Corn gluten feed }\end{array}$ & $\hat{\mathrm{Y}}=5,639-0,150 \mathrm{x}$ & 0,92 \\
\hline $\begin{array}{l}\text { Farinha de peixe } \\
\text { Fish meal }\end{array}$ & $\hat{\mathrm{Y}}=4,219-0,114 \mathrm{x}$ & 0,96 \\
\hline $\begin{array}{l}\text { Farinha de sangue } \\
\text { Blood meal }\end{array}$ & $\hat{Y}=4,802-0,103 x$ & 0,96 \\
\hline $\begin{array}{l}\text { Farinha de carne e ossos } \\
\text { Meat and bone meal }\end{array}$ & $\hat{Y}=4,433-0,104 x$ & 0,91 \\
\hline $\begin{array}{l}\text { Farinha de penas } \\
\text { Feather meal }\end{array}$ & $\hat{Y}=4,201-0,132 x$ & 0,98 \\
\hline $\begin{array}{l}\text { Farinha de vísceras de aves } \\
\text { Fowl viscera meal }\end{array}$ & $\hat{Y}=4,748-0,135 x$ & 0,98 \\
\hline $\begin{array}{l}\text { Farinha mista aves e suínos } \\
\text { Fowl-poultry viscera moisture meal }\end{array}$ & $\hat{Y}=4,630-0,163 x$ & 0,94 \\
\hline $\begin{array}{l}\text { Levedura de cana-de-açúcar } \\
\text { Sugar cane yeast }\end{array}$ & $\hat{Y}=4,208-0,087 x$ & 0,97 \\
\hline $\begin{array}{l}\text { Fubá de milho } \\
\text { Corn meal }\end{array}$ & $\hat{Y}=4,923-0,128 x$ & 0,94 \\
\hline $\begin{array}{l}\text { MDPS } \\
\text { Corn, ears and cob }\end{array}$ & $\hat{Y}=2,100-0,033 x$ & 0,96 \\
\hline $\begin{array}{l}\text { Quirera de milho } \\
\text { Grounded corn grain }\end{array}$ & $\hat{Y}=4,910-0,138 x$ & 0,90 \\
\hline $\begin{array}{l}\text { Grão de milheto moído } \\
\text { Millet grain, dry ground }\end{array}$ & $\hat{Y}=3,875-0,072 x$ & 0,96 \\
\hline $\begin{array}{l}\text { Grão de sorgo moído } \\
\text { Sorghum grain, dry ground }\end{array}$ & $\hat{Y}=3,826-0,095 x$ & 0,98 \\
\hline $\begin{array}{l}\text { Grão de amendoim moído } \\
\text { Peanut grain, dry ground }\end{array}$ & $\hat{Y}=5,601-0,118 x$ & 0,92 \\
\hline $\begin{array}{l}\text { Raspa de mandioca } \\
\text { Cassava rasp }\end{array}$ & $\hat{Y}=5,662-0,168 x$ & 0,91 \\
\hline $\begin{array}{l}\text { Polpa cítrica } \\
\text { Citrus dry pulp }\end{array}$ & $\hat{Y}=4,824-0,117 x$ & 0,95 \\
\hline $\begin{array}{l}\text { Farelo de trigo } \\
\text { Wheat bran }\end{array}$ & $\hat{Y}=5,047-0,112 x$ & 0,98 \\
\hline $\begin{array}{l}\text { Cama de frango de casca de café } \\
\text { Broiler litter using coffee as adsorvent }\end{array}$ & $\hat{Y}=5,494-0,098 x$ & 0,98 \\
\hline $\begin{array}{l}\text { Cama de frango de capim-elefante } \\
\text { Broiler litter using elephantgrass as adsorvent }\end{array}$ & $\hat{Y}=4,569-0,085 x$ & 0,98 \\
\hline $\begin{array}{l}\text { Cama de frango de cepilha de madeira } \\
\text { Broiler litter using wood rind as adsorvent }\end{array}$ & $\hat{Y}=4,388-0,096 x$ & 0,92 \\
\hline
\end{tabular}

$\mathrm{y}=\mathrm{mg} /$ tubo $(y=m g / v e s s e l)$.

$\mathrm{x}=\mathrm{mL} /$ tubo $(x=m L /$ vessel $)$. 
Tabela 4 - Estimativas das concentrações de N-solúvel em TCA (Y), em função da produção de gás (X), obtidas após 6 horas de incubação para os alimentos volumosos, e os coeficientes de determinação $\left(r^{2}\right)$

Table 4 - Estimates of N-soluble in TCA concentrations, in function of gas production, obtained after 6 hours of incubation for the forage feedstuffs, and coefficients of determination $\left(r^{2}\right)$

\begin{tabular}{lcc}
\hline $\begin{array}{l}\text { Alimentos } \\
\text { Feedstuffs }\end{array}$ & $\begin{array}{c}\text { Equações de regressão } \\
\text { Regression equations }\end{array}$ & $\mathrm{r}^{2}$ \\
\hline $\begin{array}{l}\text { Capim-braquiária } \\
\text { Signalgrass } \\
\text { Capim-braquiarão }\end{array}$ & $\hat{\mathrm{Y}}=3,77-0,24 \mathrm{x}$ & 0,97 \\
$\begin{array}{l}\text { Palisadegrass } \\
\text { Capim-braquiária do brejo }\end{array}$ & $\hat{\mathrm{Y}}=3,98-0,42 \mathrm{x}$ & 0,99 \\
$\begin{array}{l}\text { Tannergrass } \\
\text { Capim-andropogon }\end{array}$ & $\hat{\mathrm{Y}}=3,99-0,14 \mathrm{x}$ & 0,97 \\
$\begin{array}{l}\text { Gambagrass } \\
\text { Capim-gordura }\end{array}$ & $\hat{\mathrm{Y}}=4,14-0,41 \mathrm{x}$ & 0,98 \\
$\begin{array}{l}\text { Molassesgrass } \\
\text { Silagem milho }\end{array}$ & $\hat{\mathrm{Y}}=4,17-0,25 \mathrm{x}$ & 0,99 \\
$\begin{array}{l}\text { Corn silage } \\
\text { Silagem milho inoculado }\end{array}$ & $\hat{\mathrm{Y}}=4,33-0,29 \mathrm{x}$ & 0,97 \\
$\begin{array}{l}\text { Inoculated corn silage } \\
\text { Silagem sorgo } \\
\text { Sorghum silage } \\
\text { Silagem sorgo inoculado }\end{array}$ & $\hat{\mathrm{Y}}=4,06-0,17 \mathrm{x}$ & 0,99 \\
$\begin{array}{l}\text { Inoculated sorghum silage } \\
\text { Feno capim-tifton } \\
\text { Tifton 85 bermudagrass hay } \\
\text { Estilosantes guianensis }\end{array}$ & $\hat{\mathrm{Y}}=4,59-0,45 \mathrm{x}$ & 0,91 \\
Stylo & $\hat{\mathrm{Y}}=4,49-0,20 \mathrm{x}$ & 0,95 \\
\hline
\end{tabular}

$\mathrm{y}=\mathrm{mg} / \mathrm{tubo}(y=\mathrm{mg} / \mathrm{vessel})$.

$\mathrm{X}=\mathrm{mL} /$ tubo $(x=m L / v e s s e l)$.

técnica in situ. Já para o farelo de soja, Zinn et al. (1981), Van Der Aar et al. (1984) e Neutze et al. (1993) encontraram taxas de degradação semelhantes às encontradas nesta pesquisa. Com relação à proteína de escape do farelo de soja os resultados foram semelhantes aos relatados por Stern et al. (1994) e Cozzi et al. (1995), respectivamente, 22,00 e $25,70 \%$. O farelo de algodão com $30 \%$ de casca apresentou 1,35 vezes mais proteína indigerível (PIDA) que o farelo de trigo e 1,53 vezes mais do que o farelo de soja (Tabela 1), provavelmente devido à maior concentração de nitrogênio $(\mathrm{N})$ associado à fibra, que neste alimento é considerável. No que diz respeito às características cinéticas, observou-se que o farelo de soja apresentou taxa de degradação 52\% maior que a do farelo de algodão com $30 \%$ de casca e $11 \%$ maior que a do farelo de trigo. Taxas de degradação para farelo de trigo semelhantes às encontradas neste trabalho foram relatadas por Nocek et al. (1979), Ehle et al. (1982), Herrera-Saldana et al. (1986), respectivamente, $0,121 / \mathrm{h}, 0,135 / \mathrm{h}$ e $0,127 / \mathrm{h}$.

No que diz respeito ao milho e seus derivados (fubá e quirera), que apresentaram teores de proteína semelhantes (Tabela 1), observou-se que a concentração de carboidratos totais foi próxima entre esses alimentos. Entretanto, o fubá de milho apresentou concentração de carboidratos não-fibrosos $14,40 \%$ maior que a quirera de milho e $31,25 \%$ maior que o MDPS. Já a concentração de FDN corrigida e FDN indigestível corrigida foi maior para o MDPS, 26,71 e $2,70 \%$, quando comparada à do fubá de milho e da

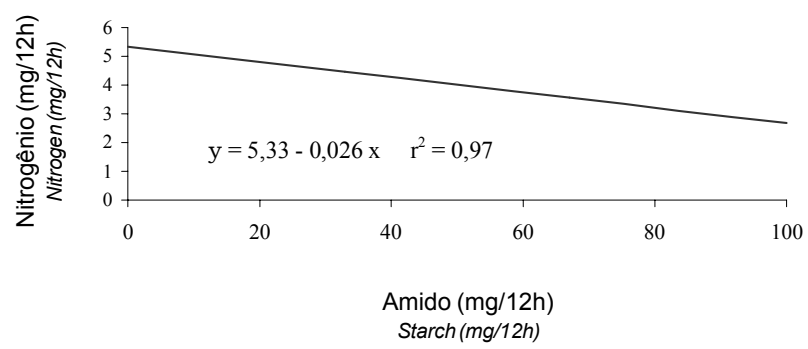

Figura 1 - Relação entre a concentração de N-solúvel (y) da caseína e a quantidade de amido (x) obtida após 12 horas de incubação.

Figure 1 - Relationship between starch and $\mathrm{N}$-soluble concentration of casein after 12 hours of incubation. 
quirera de milho 8,63 e $0,27 \%$ e 17,67 e $0,22 \%$, respectivamente. As taxas de degradação obtidas com 12 horas de incubação para o fubá de milho e a quirera de milho foram semelhantes, $0,109 / \mathrm{h}$ e $0,111 / \mathrm{h}$. Entretanto, o MDPS apresentou taxa de degradação muito lenta 0,055/h. Segundo Mertens (1989), o FDN representa os constituintes de baixa degradação dos alimentos. Zerbini \& Polan (1985), avaliando a degradabilidade ruminal da proteína, por intermédio da técnica in situ, encontraram taxa de degradação do fubá de milho de $0,114 / \mathrm{h}$ semelhante à reportada neste trabalho.

As farinhas de vísceras de aves e mista de vísceras de aves e suínos apresentaram elevado teor de proteína (Tabela 1), já a porcentagem de PIDA foi de $2,47 \%$ para a farinha mista de vísceras de aves e suínos e de $0,83 \%$ para a farinha de vísceras de aves. De acordo com Goering \& Van Soest (1970) e Pichard \& Van Soest (1977), essas fontes nitrogenadas no seu processo de fabricação formam compostos resistentes à ação dos microrganismos ruminais, sendo o PIDA a melhor forma de representar esses compostos. Os dados sobre a cinética ruminal para esses alimentos mostraram que a farinha mista de vísceras de aves e suínos apresentou menor taxa de degradação, quando comparada com a farinha de vísceras de aves, respectivamente, 0,054; 0,041 ; e 0,$122 ; 0,050 / \mathrm{h}$ para 6 e 12 horas.

Blasi et al. (1991) relataram que o processamento da farinha de penas influenciou a baix a degradabilidade ruminal desse alimento, devido à presença de ligações dissulfídicas. Aderibigbe \& Church (1983) encontraram taxa de degradação de $0,013 / \mathrm{h}$ para a farinha de penas; resultados semelhantes aos reportados nesta pesquisa. Maiga et al. (1996), avaliando a degradabilidade ruminal da proteína, por intermédio da técnica in situ, relataram taxas de degradação semelhantes às encontradas no presente trabalho para o glúten de milho e a farinha de carne e ossos. Os valores para a proteína de escape da farinha de carne e ossos $(76,92 \%)$ foram semelhantes aos $71,00 \%$ citados pelo NRC (1989).

Loerch et al. (1983) encontraram, in situ, taxa de degradação de $0,066 / \mathrm{h}$ para a farinha de sangue, resultados próximos aos observados neste experimento.

No caso dos grãos moídos de milheto, sorgo e amendoim, a concentração de carboidratos não-fibrosos foi de 66,$00 ; 69,01$; e 51,61\%. Essas concentrações poderiam, em parte, explicar a semelhança entre as taxas de degradação do sorgo e milheto.

Mustafa et al. (1999), avaliando as taxas de degradação dos farelos de trigo e de soja, utilizando o método enzimático, encontraram valores semelhantes aos obtidos no presente estudo. Valadares Filho (1994) relatou taxas de degradação obtidas in situ de $0,133 / \mathrm{h}$ para farelo de trigo e $0,049 / \mathrm{h}$ para farinha de peixe, sendo esses resultados próximos aos encontrados no presente trabalho. Vale ressaltar que as estimativas para a proteína de escape do farelo de trigo e da farinha de peixe, obtidas após 12 horas de incubação, foram próximas daquelas publicadas pelo NRC (1989).

Uma análise geral dos dados apresentados na Tabela 5 sugere que as taxas de degradação e os percentuais de escape foram superestimados para 6 horas de incubação. Assim, deve-se ressaltar que, para alimentos concentrados, o melhor tempo de incubação foi de 12 horas.

Avaliando as taxas de degradação dos volumosos (Tabela 6), no tempo 6 horas, observa-se que as silagens de sorgo sem e com inóculo, silagem de milho e o capim-gordura apresentaram proteínas de rápida degradação e a mais lenta degradação foi encontrada para o capim-braquiária. Por outro lado, a maior proteína de escape, após 6 horas de incubação, foi encontrada nos capins braquiária e Tifton, respectivamente, 53,76 e $52,08 \%$, e a menor na silagem de sorgo sem inóculo, de 21,09\%.

Com exceção das taxas de degradação encontradas para o capim-braquiária ea silagem de milho cominóculo, os valores obtidos com 6 horas de incubação foram maiores $(\mathrm{P}<0,05)$ que os de 12 horas de incubação.

O capim-braquiarão coletado no início das secas apresentou redução da porcentagem de proteína bruta em $8,00 \%$, dos carboidratos não-fibrosos em $14,00 \%$ e ligeiro aumento dos carboidratos totais e da proteína indigestível em detergente ácido (PIDA) e teve a concentração de nitrogênio não protéico $41,97 \%$ maior que o capim-braquiária (Tabela 1). Essas diferenças na composição química podem explicar a maior taxa de degradação encontrada para o capim-braquiarão. Martinez (1999), avaliando a degradabilidade ruminal de vários volumosos in situ, relatou taxa de degradação de 0,069 /h para o capimbraquiarão, sendo esse resultado próximo ao encontrado no presente trabalho.

Foram encontradas taxas de degradação e proteínas de escape próximas para os capinsandropogon, gordura e para o estilosantes, respectivamente 0,094, 0,098 e 0,094/h. Ladeira et al. (2000) encontraram taxa de degradação $(0,096 / \mathrm{h})$ seme- 
Avaliação da Composição de Vários Alimentos e Determinação da Cinética Ruminal...

Tabela 5 - Estimativas das taxas de degradação da proteína dos alimentos concentrados (Kd), desvios-padrão (DP) e proteína de escape (PE) obtidas com 6 e 12 horas de incubação, utilizando o método de produção de gás

Table 5 - Estimates of protein degradation rates for the concentrate feedstuffs (Kd), standard deviations (SD) an estimated ruminal escape $(P E)$ after 6 and 12 hours of incubation, using a gas production in vitro method

\begin{tabular}{|c|c|c|c|c|c|c|c|}
\hline \multirow{2}{*}{$\begin{array}{l}\text { Alimentos } \\
\text { Feedstuffs }\end{array}$} & \multicolumn{3}{|c|}{$6 \mathrm{~h}$} & \multicolumn{3}{|c|}{$12 \mathrm{~h}$} & \multirow[b]{2}{*}{ d } \\
\hline & $\begin{array}{l}\mathrm{Kd}(/ \mathrm{h}) \\
K d\end{array}$ & $\begin{array}{l}\text { DP } \\
S D\end{array}$ & $\begin{array}{l}\mathrm{PE}(\%) \\
P E\end{array}$ & $\begin{array}{l}\mathrm{Kd}(/ \mathrm{h}) \\
\quad K d\end{array}$ & $\begin{array}{l}\mathrm{DP} \\
S D\end{array}$ & $\begin{array}{l}\mathrm{PE}(\%) \\
P E\end{array}$ & \\
\hline Caseína & 0,242 & 0,0012 & 17,12 & 0,230 & 0,0006 & 17,85 & $0,0607^{*}$ \\
\hline $\begin{array}{l}\text { Casein } \\
\text { Farelo de soja } \\
\text { Soybean meal }\end{array}$ & 0,384 & 0,0006 & 43,40 & 0,154 & 0,0006 & 24,50 & $0,2300^{*}$ \\
\hline $\begin{array}{l}\text { Farelo de algodão } 30 \% \text { casca } \\
\text { Cottonseed meal } 30 \% \text { rind }\end{array}$ & 0,236 & 0,0091 & 17,48 & 0,073 & 0,0006 & 40,65 & $0,1630^{*}$ \\
\hline $\begin{array}{l}\text { Glúten de milho } \\
\text { Corn gluten meal }\end{array}$ & 0,102 & 0,0096 & 32,89 & 0,002 & 0,0000 & 96,15 & $0,0380^{*}$ \\
\hline $\begin{array}{l}\text { Fubá de milho } \\
\text { Corn meal }\end{array}$ & 0,116 & 0,0003 & 30,12 & 0,109 & 0,0006 & 31,44 & $0,0070^{*}$ \\
\hline $\begin{array}{l}\text { MDPS } \\
\text { Corn, ears and cob }\end{array}$ & 0,221 & 0,0010 & 18,45 & 0,055 & 0,0006 & 47,62 & $0,1656^{*}$ \\
\hline $\begin{array}{l}\text { Farelo de glúten de milho } \\
\text { Corn gluten feed }\end{array}$ & 0,382 & 0,0006 & 11,57 & 0,225 & 0,0038 & 18,18 & $0,1570^{*}$ \\
\hline $\begin{array}{l}\text { Quirera de milho } \\
\text { Grounded corn grain }\end{array}$ & 0,141 & 0,0007 & 26,17 & 0,111 & 0,0072 & 31,05 & $0,0300^{*}$ \\
\hline $\begin{array}{l}\text { Grão de milheto moído } \\
\text { Millet grain, dry ground }\end{array}$ & 0,144 & 0,0029 & 25,77 & 0,013 & 0,0000 & 79,36 & $0,1310^{*}$ \\
\hline $\begin{array}{l}\text { Grão de sorgo moído } \\
\text { Sorghum grain, dry ground }\end{array}$ & 0,155 & 0,0010 & 24,39 & 0,013 & 0,0006 & 79,36 & $0,1406^{*}$ \\
\hline $\begin{array}{l}\text { Grão de amendoim moído } \\
\text { Peanut grain, dry ground }\end{array}$ & 0,230 & 0,0012 & 17,85 & 0,203 & 0,0006 & 19,76 & $0,0270^{*}$ \\
\hline $\begin{array}{l}\text { Raspa de mandioca } \\
\text { Cassava rasp }\end{array}$ & 0,248 & 0,0010 & 16,77 & 0,245 & 0,0015 & 16,95 & $0,0026^{*}$ \\
\hline $\begin{array}{l}\text { Polpa cítrica } \\
\text { Citrus dry pulp }\end{array}$ & 0,294 & 0,0050 & 14,53 & 0,057 & 0,0057 & 46,73 & $0,2370^{*}$ \\
\hline $\begin{array}{l}\text { Farelo de trigo } \\
\text { Wheat bran }\end{array}$ & 0,203 & 0,0038 & 19,76 & 0,137 & 0,0012 & 26,73 & $0,0656^{*}$ \\
\hline $\begin{array}{l}\text { Farinha de peixe } \\
\text { Fish meal }\end{array}$ & 0,084 & 0,0010 & 37,31 & 0,038 & 0,044 & 56,82 & $0,0460 *$ \\
\hline $\begin{array}{l}\text { Farinha de sangue } \\
\text { Blood meal }\end{array}$ & 0,128 & 0,0006 & 28,08 & 0,094 & 0,0023 & 34,72 & $0,0347^{*}$ \\
\hline $\begin{array}{l}\text { Farinha de carne e ossos } \\
\text { Meat and bone meal }\end{array}$ & 0,185 & 0,0015 & 21,27 & 0,054 & 0,0040 & 48,07 & $0,1310^{*}$ \\
\hline $\begin{array}{l}\text { Farinha de penas } \\
\text { Feather meal }\end{array}$ & 0,033 & 0,0046 & 60,24 & 0,015 & 0,0010 & 76,92 & $0,0180^{*}$ \\
\hline $\begin{array}{l}\text { Farinha vísceras de aves } \\
\text { Fowl viscera meal }\end{array}$ & 0,122 & 0,0015 & 29,06 & 0,050 & 0,0012 & 50,00 & $0,0720^{*}$ \\
\hline $\begin{array}{l}\text { Farinha mista de vísceras } \\
\text { de aves e suínos }\end{array}$ & 0,054 & 0,0045 & 48,07 & 0,041 & 0,0021 & 54,94 & $0,0130^{*}$ \\
\hline $\begin{array}{l}\text { Fowl-poultry viscera moisture meal } \\
\text { Levedura de cana-de-açúcar } \\
\text { Sugar cane yeast }\end{array}$ & 0,040 & 0,0001 & 55,55 & 0,033 & 0,0002 & 60,24 & $0,0069^{*}$ \\
\hline $\begin{array}{l}\text { Cama de frango de casca de café } \\
\text { Broiler litter using coffee } \\
\text { rind as adsorvent }\end{array}$ & 0,231 & 0,0060 & 17,79 & 0,162 & 0,017 & 23,58 & $0,0680^{*}$ \\
\hline $\begin{array}{l}\text { Cama de frango de capim-elefante } \\
\text { Broiler litter using elephantgrass } \\
\text { grass as adsorvent }\end{array}$ & 0,448 & 0,0180 & 10,04 & 0,037 & 0,0010 & 57,47 & $0,4110^{*}$ \\
\hline $\begin{array}{l}\text { Cama de frango de cepilha } \\
\text { de madeira } \\
\text { Broiler litter using wood } \\
\text { rind as adsorvent }\end{array}$ & 0,039 & 0,0030 & 56,18 & 0,025 & 0,0038 & 66,66 & $0,0137^{*}$ \\
\hline
\end{tabular}

* Significativo a $5 \%$ de probabilidade pelo teste de $\mathrm{t}$.

$\mathrm{d}=\boldsymbol{\Sigma} \mathrm{di} / \mathrm{n}$ médias das diferenças.

* Significant at $5 \%$ of probability by $t$ test $(P<.05)$.

$d=\Sigma \mathrm{di} / \mathrm{n}$ means of differences.

R. Bras. Zootec., v.31, n.1, p.243-255, 2002 
Tabela 6 - Estimativas das taxas de degradação da proteína dos alimentos volumosos (Kd), desvios-padrão (DP) e proteína de escape (PE) obtidas com 6 e 12 horas de incubação, utilizando o método de produção de gás

Table 6 - Estimates of protein degradation rates for forage feedstuffs (Kd), standard deviations (SD) and estimated ruminal escape (PE) after 6 and 12 hours of incubation, using a gas production in vitro method

\begin{tabular}{|c|c|c|c|c|c|c|c|}
\hline \multirow{2}{*}{$\begin{array}{l}\text { Alimentos } \\
\text { Feedstuffs }\end{array}$} & \multicolumn{3}{|c|}{$6 \mathrm{~h}$} & \multicolumn{3}{|c|}{$12 \mathrm{~h}$} & \multirow[b]{2}{*}{$\mathrm{d}$} \\
\hline & $\begin{array}{c}\mathrm{Kd}(/ \mathrm{h}) \\
K d\end{array}$ & $\begin{array}{l}\text { DP } \\
S D\end{array}$ & $\begin{array}{l}\mathrm{PE}(\%) \\
P E\end{array}$ & $\begin{array}{l}\mathrm{Kd}(/ \mathrm{h}) \\
K d\end{array}$ & $\begin{array}{l}\mathrm{DP} \\
S D\end{array}$ & $\begin{array}{l}\mathrm{PE}(\%) \\
P E\end{array}$ & \\
\hline $\begin{array}{l}\text { Capim-braquiária } \\
\text { Signalgrass }\end{array}$ & 0,043 & 0,0001 & 53,76 & 0,042 & 0,0002 & 54,34 & $0,001^{\mathrm{NS}}$ \\
\hline $\begin{array}{l}\text { Capim-braquiarão } \\
\text { Palisadegrass }\end{array}$ & 0,071 & 0,0035 & 41,32 & 0,003 & 0,0000 & 94,33 & $0,0684 *$ \\
\hline $\begin{array}{l}\text { Capim-braquiária do brejo } \\
\text { Tannergrass }\end{array}$ & 0,072 & 0,0020 & 40,98 & 0,016 & 0,0000 & 75,75 & $0,0560^{*}$ \\
\hline $\begin{array}{l}\text { Capim-Andropogon } \\
\text { Gambagrass }\end{array}$ & 0,094 & 0,0044 & 34,72 & 0,003 & 0,0000 & 94,33 & $0,0910^{*}$ \\
\hline $\begin{array}{l}\text { Capim-gordura } \\
\text { Honeygrass }\end{array}$ & 0,098 & 0,0006 & 33,78 & 0,024 & 0,0006 & 67,56 & $0,0730^{*}$ \\
\hline $\begin{array}{l}\text { Silagem milho } \\
\text { Corn silage }\end{array}$ & 0,126 & 0,0021 & 28,40 & 0,030 & 0,0006 & 62,50 & $0,0950^{*}$ \\
\hline $\begin{array}{l}\text { Silagem milho inoculado } \\
\text { Inoculated corn silage }\end{array}$ & 0,082 & 0,0000 & 37,87 & 0,080 & 0,0001 & 38,46 & $0,002^{\mathrm{NS}}$ \\
\hline $\begin{array}{l}\text { Silagem sorgo } \\
\text { Sorghum silage }\end{array}$ & 0,187 & 0,0006 & 21,09 & 0,164 & 0,0010 & 23,36 & $0,0230^{*}$ \\
\hline $\begin{array}{l}\text { Silagem sorgo inoculado } \\
\text { Inoculated sorghum silage }\end{array}$ & 0,159 & 0,0042 & 23,92 & 0,077 & 0,0021 & 39,37 & $0,0820^{*}$ \\
\hline $\begin{array}{l}\text { Feno capim-Tifton } \\
\text { Tifton } 85 \text { bermudagrass hay }\end{array}$ & 0,046 & 0,0006 & 52,08 & 0,031 & 0,0000 & 61,73 & $0,0148^{*}$ \\
\hline $\begin{array}{l}\text { Estilosantes guianensis } \\
\text { Stylo }\end{array}$ & 0,094 & 0,0029 & 34,72 & 0,013 & 0,0006 & 79,36 & $0,0801^{*}$ \\
\hline
\end{tabular}

* Significativo a $5 \%$ de probabilidade pelo teste de $\mathrm{t}$ (Significant at $5 \%$ of probability by $t$ test $[P<0.05]$ ).

$\mathrm{d}=\boldsymbol{\Sigma} \mathrm{di} / \mathrm{n}$ médias das diferenças, NS - Não-significativo ( $d=\boldsymbol{\Sigma}$ di/n means of differences, NS - Not significant).

lhante à obtida na presente pesquisa para $o$ estilosantes após 6 horas de incubação.

Com relação às estimativas da degradação das silagens de milho e sorgo, após 6 horas de incubação, observou-se que a inoculação das silagens diminuiu as taxas de degradação, 35,00 e 15,00\%, respectivamente. Esses resultados mostraram que o método de produção de gás foi eficiente na determinação do efeito do inoculante microbiano na degradação ruminal desses alimentos. As estimativas da proteína não- degradada no rúmen da silagem de milho, após 6 horas de incubação, foi de $28,40 \%$. Esses resultados foram próximos aos relatados pelo NRC (1989), de 31,00\%.

\section{Conclusões}

Recomenda-se usar o tempo de 12 horas para avaliar os alimentos concentrados e 6 horas para os volumosos.

\section{Literatura Citada}

ADERIBIGBE, A.O.; CHURCH, D.C. Feather and hair meals for ruminants. III. Relationship between enzymatic or in vitro rumen digestibility and in vivo digestibility of diets

R. Bras. Zootec., v.31, n.1, p.243-255, 2002 containing feather and hair meals. Journal of Animal Science, v.57, n.2, p.483-494, 1983.

ASSOCIATION OF OFFICIAL ANALYTICAL CHEMISTS AOAC. Official methods of analysis. 15.ed., Arlington: 1990. v.1, 117p.

BLASI, D.A.; KLOPFENSTEIN, T.J.; DROUILLARD, J.S. et al. Hydrolysis time as a factor affecting the nutritive value of feather meal and feather meal-blood meal combinations for growing calves. Journal of Animal Science, v.69, n.4, p.1272-1278, 1991.

BRODERICK, G.A. Methodology for the determining ruminal degradability of feed proteins. In: SIMPÓSIO INTERNACIONAL SOBRE EXIGÊNCIAS NUTRICIONAIS DE RUMINANTES, 1995, Viçosa, MG. Anais... Viçosa: Universidade Federal de Viçosa, 1995. p.139-176.

BRODERICK, G.A.; WALLACE, R.J. Effects of dietary nitrogen source on concentrations of ammonia, free amino acids and fluorescamine reactive peptides in the sheep rumen. Journal of Animal Science, v.66, n.9, p.2233-2238, 1988.

BRODERICK, G.A.; CRAIG, W.M. Mechanism of protein degradation by rumen microbes. Federation Proceedings, v.42, p.532, 1983. (Abstr.).

CHAMBERLAIN, D.G.; THOMAS, P.C. Prospective laboratory methods for estimating the susceptibility of feed proteins to microbial breakdown in the rumen. Proceeding Nutrition Society, v.38, p.138A, 1979.

CHEN, G.; SNIFFEN, C.J.; RUSSELL, J.B. Concentration and estimated flow of peptides from the rumen of dairy cattle: effects 
of protein quantity, protein solubility, and feeding frequency. Journal of Dairy Science, v.70, n.5, p.983-992, 1987.

COZZI, G.; ANDRIOGHETTO, I.; BERZAGHI, P. et al. In situ ruminal disappearance of essential amino acids in protein feedstuffs. Journal of Dairy Science, v.78, p.161-171, 1995.

EHLE, F.R.; MURPHY, M.R.; CLARK, J.H. In situ particle size reduction and the effect of particle size on degradation of crude protein and dry matter in the rumen of dairy cows. Journal of Dairy Science, v.65, n.6, p.963-971, 1982.

GOERING, H.K.; Van SOEST, P.J. Forage fiber analyses (apparatus, reagents, procedures, and some applications). Washington, D.C.: ARS-USDA, 1970. (Agriculture Handbook, 379)

HATFIELD, R.D. Structural polysaccharides in forages and their degradability. Agronomy Journal, v.81, n.1, p.39-46, 1989.

HERRERA-SALDANA, R.; HUBER, J.T.; SWINGLE, R.S. Protein and starch solubility and degradability of several common feedstuffs. Journal of Dairy Science, v.69, S1, p.141, 1986. (Abstract).

KRISHNAMOORTHY, U.; STEINGASS, H.; MENKE, K.H. The contribution of ammonia, amino acids and short peptides to estimates of protein degradability in vitro. Journal of Animal Physiology Animal Nutrition, v.63, n.2, p.135-141, 1990.

LADEIRA, M.M.; RODRIGUEZ, M.N.; GONÇALVES, L.C. et al. Avaliação nutricional do feno de stylosantes guianensis. 3. Degradabilidade ruminal e taxa de passagem. In: REUNIÃO ANUAL DA SOCIEDADE BRASILEIRA DE ZOOTECNIA, 37., Viçosa, MG, 2000. Anais... Viçosa: Sociedade Brasileira de Zootecnia, 2000. p.349-350.

LICITRA, G.; HERNANDEZ, T.M.; VAN SOEST, P.J. Standardization of procedures for nitrogen fractionation of ruminant feeds. Animal Feed Science and Technology, v.57, n.3, p.347-358, 1996.

LOERCH, S.C.; BERGER, L.L.; GIANOLA, D. et al. Effects of dietary protein source and energy level on in situ nitrogen disappearance of various protein sources. Journal of Animal Science, v.56, n.1, p.206-216, 1983.

MAENG, W.J.; Van NEVEL, C.J.; BALDWIN, R.L. et al. Rumen microbial growth rates and yields: effect of amino acids and protein. Journal of Dairy Science, v.59, n.1, p.68-79, 1975.

MAIGA, H.A.; SCHINGOETHE, J.D.; HENSON, J.E. Ruminal degradation, amino acid composition, and intestinal digestibility of the residual components of five protein supplements. Journal of Dairy Science, v.79, n.9, p.1647-1653, 1996.

MARTIINEZ, V.L.R. Composição química e degradabilidade in situ de volumosos e concentrados determinada em bubalinos e bovinos. Recife, PE: Universidade Federal Rural de Pernambuco, 1999. 59p. Dissertação(Mestrado emZootecnia) - Universidade Federal Rural de Pernambuco, 1999.

MENKE, K.H.; RAAB, L.B.; SALEWSKI, A. et al. The estimation of the digestibility and metabolizable energy content of ruminal feeding stuffs from the gas production when they are incubated with rumen liquor in vitro. Journal of Agriculture Science, v.93, n.4, p.217-222, 1979.

MERTENS, D.R. Fiber analysis and its use in ration formulation. In: ANNUAL PACIFIC NORTWEST ANIMAL NUTRITION CONFERENCE, 24., 1989, Idaho. Proceedings... Idaho: Riverside Boise, 1989. p.1-10.

MILLER, E.L. Methods of assessing proteins for ruminants including laboratory methods In: Protein contribution of feedstuffs for ruminants. Boston: Butterwords, 1982. p.18-32.

MUSTAFA, A.F.; McKINNON, J.J.; CHRISTENSEN, D.A. Chemical characterization and in vitro crude protein degradability of thin stillage derived from barley and wheatbased ethanol production. Animal Feeding Science and Technology, v.80, p.247-256, 1999.
NATIONAL RESEARCH COUNCIL - NRC. Nutrient requirements of dairy cattle. 6.rev.ed (update 1989). Washington, D.C.: 1989. 157p.

NEUTZE, S.A., SMITH, R.L., FORBES, W.A. Application of an inhibitor in vitro method for estimating rumen degradation of feed protein. Animal Feeding Science Technology, v.40, n.1, p.251-265, 1993.

NOCEK, J.E., RUSSELL, J.B. Protein and energy as an integrated system. Relationship of ruminal protein and carbohydrate availability to microbial synthesis and milk production. Journal of Dairy Science, v.71, n.8, p.2070-2107, 1988.

NOCEK, J.E.; CUMMINS, K.A.; POLAN, C.E. Ruminal disappearance of crude protein and dry matter in feeds and combined effects in formulated rations. Journal of Dairy Science, v.62, n.10, p.1587-1598, 1979.

PELL, A.N.; SCHOFIELD, P. Computerized monitoring of gas production to measure forage digestion in vitro. Journal of Dairy Science, v.76, n.4, p.1063-1073, 1993.

PICHARD, G.R.; Van SOEST, P.J. In: CORNELL NUTRITION CONFERENCE FOR FEED MANUFACTURES, 1977. Proceedings... s.1., 1977. p.91.

RAAB, L.B.; CAFANTARIS, T.J.; MENKE, K.H. Rumen protein degradation and biosynthesis. 1. A new method for determination of protein degradation in rumen fluid in vitro. British Journal Nutrition, v.50, n.5, p.569-582, 1983.

RUSSELL, J.B.; SNIFFEN, C.J.; Van SOEST, J.P. Effect of carbohydrate limitation on degradation and utilization of casein by mixed rumen bacteria. Journal of Dairy Science, v.66, n.3, p.763-782, 1983.

RUSSELL, J.B.; O'CONNOR, J.D.; FOX, D.G. et al. A net carbohydrate and protein system for evaluating cattle diets: I. Ruminal fermentation. Journal of Animal Science, v.70, n.12, p.3551-3561. 1992.

SNIFFEN, C.J.; O'CONNOR, J.D.; Van SOEST, P.J. et al. A net carbohydrate and protein system for evaluating cattle diets: II. Carbohydrate and protein availability. Journal of Animal Science, v.70, n.12, p.3562-3577, 1992.

STERN, M.D.; VARGA, G.A.; CLARK, J.H. et al. Symposium: metabolic relationships in supply of nutrients for milk protein synthesis. Evaluation of chemical and physical properties of feeds that affect protein metabolism in the rumen. Journal of Dairy Science, v.77, n.11, p.2762-2786, 1994.

VALADARES FILHO, S.C. Utilização da técnica in situ para avaliação dos alimentos. In: SIMPÓSIO INTERNACIONAL DE PRODUÇÃO DE RUMINANTES, 1994, Maringá. Anais... Maringá: Sociedade Brasileira de Zootecnia, 1994. p.95-118.

VAN DER AAR, P.J.; BERGER, L.L.; FAHET, G.C. et al. Effect of alcohol treatments of soybean meal on ruminal escape of soybean meal protein. Journal of Animal Science, v.59, n.2, p.483-489, 1984.

VAN SOEST, P.J.; ROBERTSON, J.B.; LEWIS, B.A. Methods for dietary fiber, neutral detergent fiber, and nonstarch polysaccharides in relation to animal nutrition. Journal of Dairy Science, v.74, n.10, p.3583-3597, 1991.

ZERBINI, E.; POLAN, C.E. Protein sources evaluated for ruminating holstein calves. Journal of Dairy Science, v. 68 , n.5, p.1416-1424, 1985

ZINN, R.A.; BULL, L.S.; HEMKEN, R.W. Degradation of supplemental proteins in the rumen. Journal of Animal Science, v.52, n.4, p.857-866, 1981. 